\title{
Decoding of movement direction using optical imaging of motor cortex
}

\author{
Nicoladie D Tam ${ }^{1 *}$, George Zouridakis ${ }^{2}$ \\ From Twenty Second Annual Computational Neuroscience Meeting: CNS*2013 \\ Paris, France. 13-18 July 2013
}

This study provides a computational scheme to decode intentional arm movement direction using optical imaging of the motor cortex for future implementation on a neuroprosthetic device that enables physically disabled patients to navigate a wheelchair using brain-derived signals. To this end, we developed a signal-processing algorithm for detecting movement direction from hemodynamic signals using functional near-infrared spectroscopy (fNIRS) recorded in human subjects during execution of a directional motor task. fNIRS has been shown to reflect hemodynamic responses in the cortex during execution of computational $[1,4,6]$ and motor tasks [2], and can capture better regional cerebral blood volume (rCBV) changes [3] than blood-oxygen level dependent (BOLD) signals [5]. We used 64 spatially distributed optrodes to record from both hemispheres of motor cortices during free arm orthogonal movements in the $x$ and $y$ directions on a horizontal plane, extending the experimental findings reported earlier [7]. We then analyzed the spatiotemporal profiles of the 64-channel hemodynamic response to derive the direction of the movement executed from the motor cortex activation.

We employed four different measures of hemodynamic profiles - oxy- $\left(\mathrm{HbO}_{2}\right)$ and deoxy-hemoglobin $(\mathrm{Hb})$, and their sum $\left(\mathrm{HbO}_{2}+\mathrm{Hb}\right)$ and difference $\left(\mathrm{HbO}_{2}-\mathrm{Hb}\right)$ signals - to correlate oxygen delivery, oxygen extraction, total blood volume delivered, and total oxygenation with a series of specific movements to identify the direction of the intentional movements. This analysis provided a unique representation of the different hemodynamic components of the localized neuronal populations in the motor cortices underlying the optrodes.
Our results show that the four measures of hemodynamic response may be coupled in one movement direction and decoupled in another, for the same subject. That is, oxygen delivery, extraction, total blood volume, and oxygenation do not necessarily co-vary (increase or decrease simultaneously) for all movement directions, but for some directions, they may be decoupled; e.g., oxygen delivery may increase while, at the same time, oxygen extraction may decrease. This suggested that oxygen extraction may outpace oxygen delivery due to high oxygen demand of the underlying neural tissues, resulting in decoupling of the oxygen delivery and extraction variables. Thus, if decoding of movement direction relies on a single hemodynamic measure, the latter is not sufficient to identify the movement direction uniquely. Instead, a combination of all four measures of hemodynamic signals is needed, and it can be extracted from the temporal profiles of neural activation and deactivation that represent temporal coupling and decoupling of oxygen delivery and extraction. Overall, our experiments demonstrate the feasibility of decoding intentional movement direction using computational analysis of optical recordings from the motor cortex, instead of implanting microelectrodes, and support a future implementation of a hands-free neuroprosthetic device for the physically disabled to navigate a wheelchair unassisted.

\footnotetext{
Author details

${ }^{1}$ Department of Biological Sciences, University of North Texas, Denton, TX 76203, USA. ²Departments of Engineering Technology, Computer Science, and Electrical and Computer Engineering, University of Houston, Houston, TX, 77204, USA.
}

Published: 8 July 2013

\footnotetext{
* Correspondence: nicoladie.tam@unt.edu

'Department of Biological Sciences, University of North Texas, Denton, TX 76203, USA

Full list of author information is available at the end of the article
}

(c) 2013 Tam and Zouridakis; licensee BioMed Central Ltd. This is an Open Access article distributed under the terms of the Creative 


\section{References}

1. Calderon-Arnulphi M, Alaraj A, Slavin KV: Near infrared technology in neuroscience: past, present and future. Neurol Res 2009, 31(6):605-614.

2. Colier WNJM, Quaresima V, Brattelli G, Cavallari P, van der Sluijs M, Ferrari M: Detailed evidence of cerebral hemoglobin oxygenation changes in response to motor activation revealed by a continuous wave spectrophotometer with $10 \mathrm{~Hz}$ temporal resolution. Proc SPIE 1997, 2979:390-396.

3. Deply DT, Cope M, van der Zee P, Aguirre GK, Wray S, Wyatt J: Estimation of optical pathlength through tissue from direct time of flight measurement. Phys Med Bio 1998, 33:1433-1442.

4. Hoshi Y: Towards the next generation of near-infrared spectroscopy. Philos Transact A Math Phys Eng Sci 2011, 369(1955):4425-4439.

5. Huppert TJ, Hoge RD, Diamond SG, Franceschini MA, Boas DA: A temporal comparison of BOLD, ASL and NIRS hemodynamic responses to motor stimuli in adult humans. Neuroimage 2006, 29(2):368-382.

6. Pellicer A, Bravo Mdel C: Near-infrared spectroscopy: a methodologyfocused review. Semin Fetal Neonatal Med 2011, 16(1):42-49.

7. Tam ND, Zourikakis G: Optical imaging of motor cortical activation using functional near-infrared spectroscopy. BMC Neuroscience 2012, 13(Suppl 1):P27.

doi:10.1186/1471-2202-14-S1-P380

Cite this article as: Tam and Zouridakis: Decoding of movement direction using optical imaging of motor cortex. BMC Neuroscience 2013 14(Suppl 1):P380.

\section{Submit your next manuscript to BioMed Central} and take full advantage of:

- Convenient online submission

- Thorough peer review

- No space constraints or color figure charges

- Immediate publication on acceptance

- Inclusion in PubMed, CAS, Scopus and Google Scholar

- Research which is freely available for redistribution

Submit your manuscript at www.biomedcentral.com/submit
Biomed Central 